\title{
The implementation of Quizizz-based online evaluation in higher education: an exciting alternative for evaluation
}

\author{
Anggarda Paramita Muji ${ }^{1}$, Ambiyar $^{2}$, Ishak Aziz ${ }^{2}$, Hendra Hidayat ${ }^{2 *}$ \\ ${ }^{1}$ Doctoral Program Student of Educational Sciences, Universitas Negeri Padang, Indonesia \\ ${ }^{2}$ Universitas Negeri Padang, Indonesia \\ *Corresponding author, e-mail: hendra.hidayat@ft.unp.ac.id
}

\begin{abstract}
The challenges of online learning during the Covid-19 pandemic require creativity and learning innovation, so online learning evaluation is very much needed. The purpose of this paper is to explore the implementation of Quizizz-based online evaluation in universities as a fun alternative to evaluation. Quizizz has adequate features to serve as a means of evaluating online learning such as quizzes and daily assessments. However, most of them only use Quizizz as a learning game, whereas through Quizizz various formal learning evaluations can be carried out such as quizzes, daily assessments, surveys and so on. This research method is a qualitative method. Methods of collecting data with literature review, observation, and interviews. Sampling was selected by purposive sampling method.There are 56 students from the class of 2021 who are taking electronic components lectures, of which 21 are male and 35 are female, ranging in age from 19 to 20 years. The results of the study found that the implementation of Quizizz is easy to use, has many features and many facilities that support learning evaluation activities. Furthermore, the use of features on Quizizz, such as Live Quiz, gives the impression of live evaluation which is fun. Learning evaluation through Quizizz can make it easier for lecturers to make detailed and objective assessments. So, with the current Covid-19 pandemic, learning evaluation with Quizizz is the right alternative.
\end{abstract}

Keywords: Quizizz, Online Evaluation, Higher Education

How to Cite: Muji, A. P., Ambiyar, A., Aziz, I. \& Hidayat, H. (2021). The implementation of Quizizzbased online evaluation in higher education: an exciting alternative for evaluation. International Journal of Research in Counseling and Education, 5 (2): pp. 186-194, DOI: https://doi.org/10.24036/00478za0002

This is an open access article distributed under the Creative Commons 4.0 Attribution License, which permits unrestricted use, distribution, and reproduction in any medium, provided the original work is properly cited. @2021 by Author.

\section{Introduction}

The implementation of the learning process cannot be separated from assessment activities, including learning evaluation (Baartman et al., 2007), as well as online evaluation during the Covid-19 pandemic (Ardi et al., 2021). When people learn, the response becomes stronger, if he does not learn the response decreases. In learning, there are opportunities for events that cause learning responses, learning responses, consequences that are reinforcing the response (Sadler, 2010). Learning is an attempt to shape the desired behavior. Learning as a way for educators to provide opportunities for students to think in order to recognize and understand something that is being studied (Nilsson, 2008). Learning also gives freedom to students to choose learning materials and how to study them according to their abilities (Abidah et al., 2020). Learning is every systematic and deliberate effort to create educational interaction activities between two parties, namely between students and educators who carry out learning activities (Bovill, 2020). Learning is an attempt to make students learn and an activity to teach. So that learning is an effort made to create a teaching and learning process. Learning here emphasizes more on how the efforts of educators to encourage or facilitate students in learning, especially to motivate students in learning (Brassler, \& Dettmers, 2017). namely between students and educators who carry out learning activities (Bovill, 2020). Learning is an attempt to make students learn and an activity to teach. So that learning is an effort made to create a teaching and learning process. Learning here emphasizes more on how the efforts of educators to encourage or facilitate students in learning, especially to motivate students in learning (Brassler, \& Dettmers, 2017). namely between students and educators who carry out learning activities (Bovill, 2020). Learning is an attempt to make students learn and an activity to teach. So that 
learning is an effort made to create a teaching and learning process. Learning here emphasizes more on how the efforts of educators to encourage or facilitate students in learning, especially to motivate students in learning (Brassler, \& Dettmers, 2017).

The challenges of the pandemic, and the Industrial Revolution 4.0 in all fields of science, especially in the field of education, is no exception in higher education by optimizing technology-based learning (Anwar et al., 2021). To develop all students' potential, both cognitively, affectively, and psychomotorically, they must go through a learning process in the world of digital-based education (Okay, \& Fernandes, 2020), and creative and innovative learning models (Ganefri et al., 2021; Hidayat et al., 2018; Hidayat, 2017). In addition to the learning process, the learning evaluation process is also the focus of educators in implementing teaching by implementing the Indonesian National Qualifications Framework curriculum. In accordance with the demands of the curriculum and the industrial revolution 4.0, educators must be able to create creative learning, which is able to create an effective learning atmosphere so that students' learning concentration is in an effort to achieve quality education quality standards. Learning evaluation is an important aspect of the learning process. By evaluating learning, educators can find out how successful the delivery of material is during teaching and learning activities. Learning evaluation is a process to determine the value of everything in learning.

Learning evaluation can also be done through quizzes or games related to the lecture material that has been delivered. One alternative to online-based learning evaluation is to use quizzz (Asria, \& Putrie, 2021; Zuhriyah, \& Pratolo, 2020). Quizizz provides data and statistics about student performance, and you can even download these statistics in the form of an Excel spreadsheet. Lecturers can track the number of students' answers. The use of quizizz helps educators in conducting evaluations without being limited by place, an attractive display and set time settings guide students' concentration. Quizizz is a game-based educational app, which brings multiplayer activities to the classroom and makes in-class practice fun and interactive. By using Quizizz, students can do the exercises in class on their electronic devices. Unlike other educational apps, Quizizz has game characteristics such as avatars, themes, memes, and entertaining music in the learning process.

Quizizz also allows students to compete with each other and motivates them to learn (Amalia, 2020). Learners take quizzes at the same time in class and see their live ranking on the leaderboard. Instructors can monitor the process and download reports when quizzes are completed to evaluate student performance. Using this application helps stimulate interest and increase students' concentration (Zhao, 2019). Through Quizizz, educators can see the level of mastery of the material possessed by students. Besides Quizizz, it can increase student activity in online learning. However, unfortunately Quizizz has not been used as a learning evaluation medium as a benchmark for assessment because it is only considered a game or game. Even though the Quizizz feature is quite feasible if it is used as an evaluation medium, especially during online learning (Darmawan et al., 2020). Quizizz is an application that is suitable for use as a learning application that supports the 4.0 learning revolution because of its easy use and fast assessment process. By utilizing this application, students have easy access to interactive and fun learning resources (Suo Yan, \& Mei, 2018). In addition, parents can also actively participate in monitoring the material presented by educators. Based on the explanation above, the purpose of this paper is to explain the implementation of Quizizz as an alternative to online evaluation in higher education.

Quizizz is an application that is suitable for use as a learning application that supports the 4.0 learning revolution because of its easy use and fast assessment process. By utilizing this application, students have easy access to interactive and fun learning resources (Suo Yan, \& Mei, 2018). In addition, parents can also actively participate in monitoring the material presented by educators. Based on the explanation above, the purpose of this paper is to explain the implementation of Quizizz as an alternative to online evaluation in higher education. Quizizz is an application that is suitable for use as a learning application that supports the 4.0 learning revolution because of its easy use and fast assessment process. By utilizing this application, students have easy access to interactive and fun learning resources (Suo Yan, \& Mei, 2018). In addition, parents can also actively participate in monitoring the material presented by educators. Based on the explanation above, the purpose of this paper is to explain the implementation of Quizizz as an alternative to online evaluation in higher education. \& May, 2018). In addition, parents can also actively participate in monitoring the material presented by educators. Based on the explanation above, the purpose of this paper is to explain the implementation of Quizizz as an alternative to online evaluation in higher education. \& May, 2018). In addition, parents can also actively participate in monitoring the material presented by educators. Based on the explanation above, the purpose of this paper is to explain the implementation of Quizizz as an alternative to online evaluation in higher education.

\section{Method}

The method used in this research is qualitative research. Qualitative research emphasizes holistic description, which is a detailed description of everything that happens in certain activities or situations (Mohajan, 2018). Methods of collecting data with literature review, observation, and interviews. The object of this research is Quizizz. Quizizz is a gamified student engagement platform that offers multiple features to 
make a classroom fun, interactive, engaging, free, open access and makes classroom learning more fun and interactive (Purba, 2019). Quizizz is one of the media that can help lecturers in conducting online tests. This research was conducted in September 2021. In the Quizizz learning evaluation trial, the research population was all students of Electronic Engineering Education, Faculty of Engineering, Padang State University. Sampling was selected using the purposive sampling method, namely the class of 2021 students who are taking electronic components lectures totaling 56 people, with 21 males and 35 females, ages ranging from 19-20 years.

\section{Results and Discussion}

Innovation of learning models in higher education during the pandemic and Industrial Revolution 4.0 became an urgent need (Hidayat et al., 2019a; 2019b). Online learning requires educators to look for various digital platforms that are easily accessible for lecturers and students so that learning takes place effectively and efficiently and gets good quality. Based on observations, interactive online learning through google meet or zoom is not running effectively due to poor signal constraints and wasteful quota. Therefore, the implementation of learning through google meet or zoom is only done a few times, the rest of the lecturers use whatsapp groups as a liaison media between lecturers and students online. Through the whatsapp group, lecturers carry out teaching activities by sharing learning links, (containing materials/modules), video links, voicenotes, pictures, quiz or test links (google forms, quizizz, etc.), attendance links and conducting discussions or questions and answers, and there are also one that optimizes the university's e-learning platform. The same is also applied to activities at Padang State University, including the Electronic Engineering Education Study Program. In an online learning meeting, the lecturer conveys material through videos/voicenotes in stages according to the existing material. With the gradual delivery of material, lecturers can provide opportunities for students to respond or ask questions before continuing to deliver the next material. However, because of time constraints the lecturer cannot wait for all students to respond to the material presented. So that there are only a few students who can respond during teaching and learning activities at the zoom meeting. Therefore, evaluation of learning in the form of quizzes at each online meeting is very necessary to see the ability of students to master the material presented.

Based on the results of interviews with lecturers of the electronics component course in the electronics engineering study program, quizzes were given at the end of the meeting through Quizizz. The results of Quizizz are not used as a benchmark for assessing student assignments, because lecturers think that Quizizz is an alternative learning that can attract students to learn. However, the features in Quizizz are very supportive to make Quizizz a true learning evaluation tool. Therefore, it is very necessary to describe the features and their use on Quizizz so that Quizizz users can take full advantage of Quizizz, as follows:

\section{Quizizz Account Creation}

(1) To evaluate learning in Quizizz, lecturers must sign up via email or google account on the website www.quizizz.com; (2) Choose usage, namely on campus/school., (3) Choose as a lecturer.

\section{Quiz or Test Creation}

(1) Click Create; (2) Write the name of the quiz, for example, Electronic Component Quiz; (3) Select the relevant material that has been provided by the application system, then click Next; (4) Choose the type of quiz. There are five types of quizzes, namely Multiple Choice, Checkbox, Fill-in-the-Blank, Poll, and Open Ended. Multiple Choice is a quiz in the form of multiple choices where the lecturer can provide the number of answer options according to the lecturer's needs. Checkbox and Multiple Choice are not much different, the difference is only if the Checkbox can provide more than one correct answer. Fill-in-the-Blank is a question that is written in an incomplete or blank sentence. Poll is a type of quiz where there is no right or wrong answer for each answer choice. Meanwhile, Open Ended is a quiz in the form of an essay so that there are no answer options; (5) Write down the questions. Questions can be typed or can be in the form of image, audio or video media. In addition, there is also a feature to write questions in the form of equations or mathematical formulas. If there are mathematical symbols that are not available in the Quizizz feature, the lecturer can provide the question through pictures; (6) Write down the answer choices. Answers can be written manually or through pictures; (7) Determine the estimated processing time; (8) Save the work by clicking save; (9) Write down the following questions according to steps 1-9; (10) Click Done if all questions are completed; (11) Choose the type of quiz implementation, namely Live Quiz or Homework. The implementation of the live quiz is when the lecturer has given the quiz link and it is done right away. While the implementation of Homework is according to the time span given by the lecturer. For evaluation of learning in the form of exams, lecturers should choose Live Quiz; (12) Select Exam mode; (13) Click Next after setting some advanced settings according to the needs of the lecturer such as the number of experiments carried out by students, showing students correct answers, showing all student questions and answers at the end of the quiz, setting background music, memes, and so on; (14) Share Quizizz code or link to students; (15) Click Start, if all or the majority of students have joined the quiz. (13) Click Next after setting some advanced settings according to the needs of the lecturer such as the 
number of experiments carried out by students, showing students correct answers, showing all student questions and answers at the end of the quiz, setting background music, memes, and so on; (14) Share Quizizz code or link to students; (15) Click Start, if all or the majority of students have joined the quiz. (13) Click Next after setting some advanced settings according to the needs of the lecturer such as the number of experiments carried out by students, showing students correct answers, showing all student questions and answers at the end of the quiz, setting background music, memes, and so on; (14) Share Quizizz code or link to students; (15) Click Start, if all or the majority of students have joined the quiz.

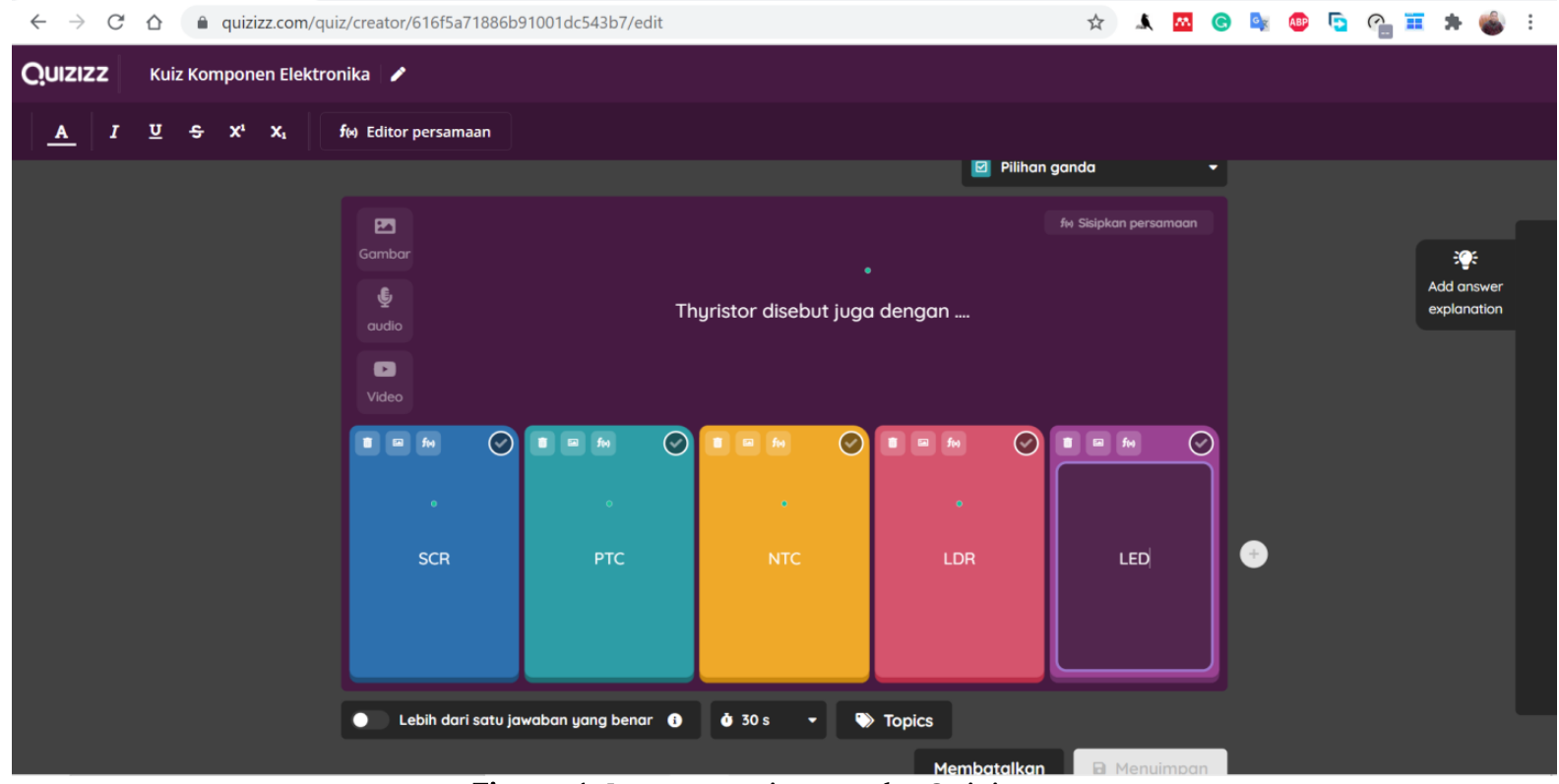

Figure 1. Input questions to the Quizizz system

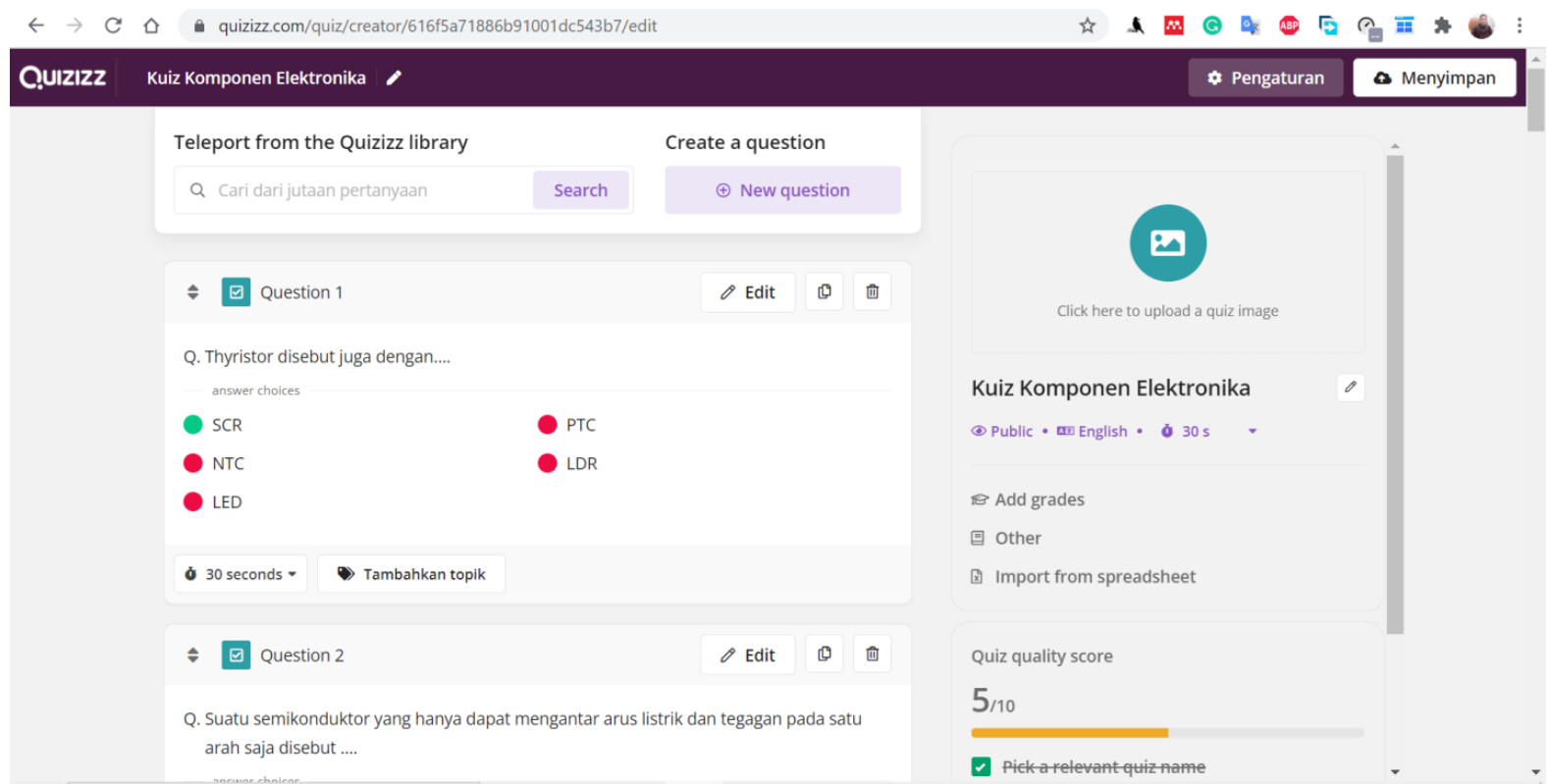

Figure 2. Display of the output of the question after it is entered in the Quizizz system 


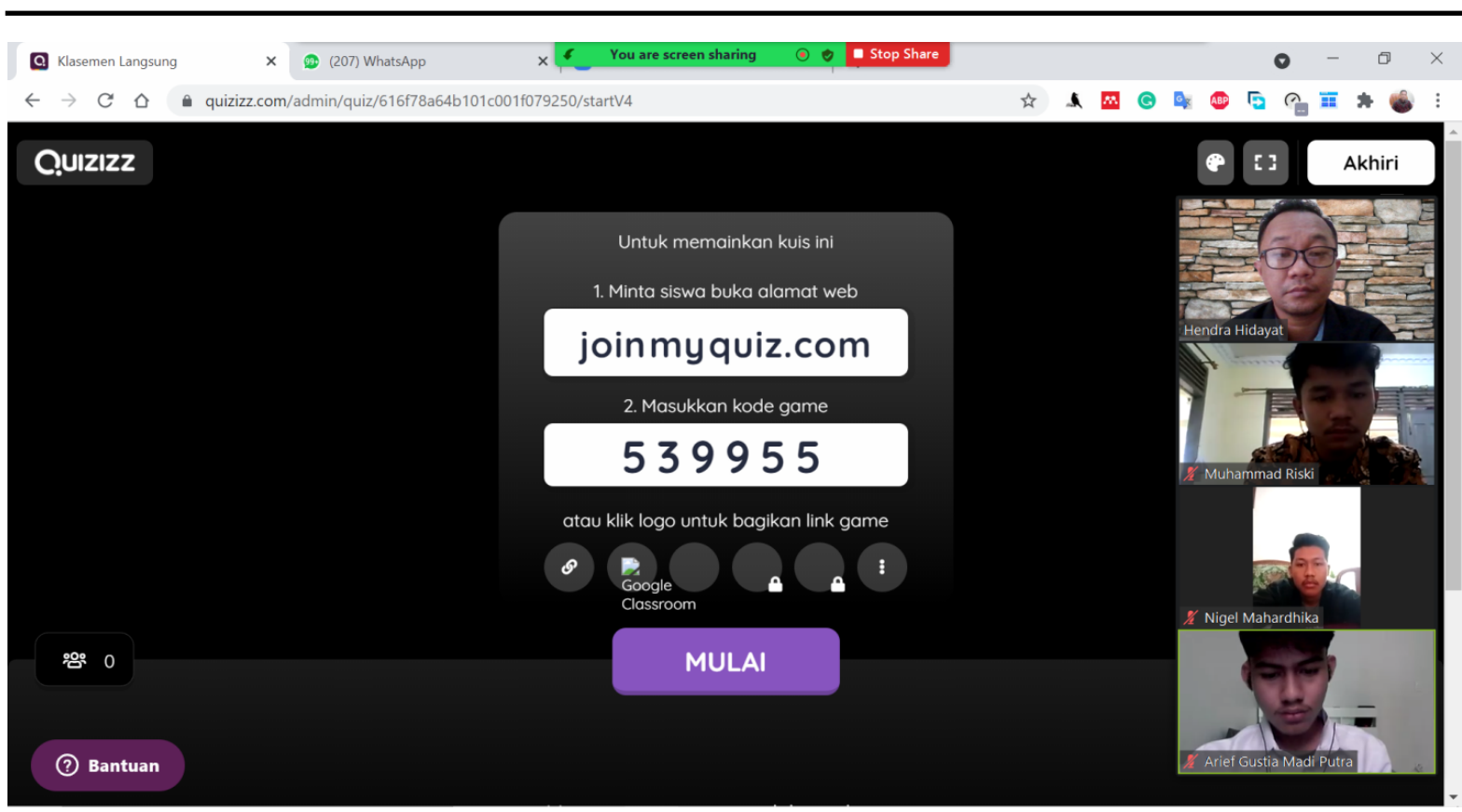

Figure 3. Quizizz is ready to start with game code

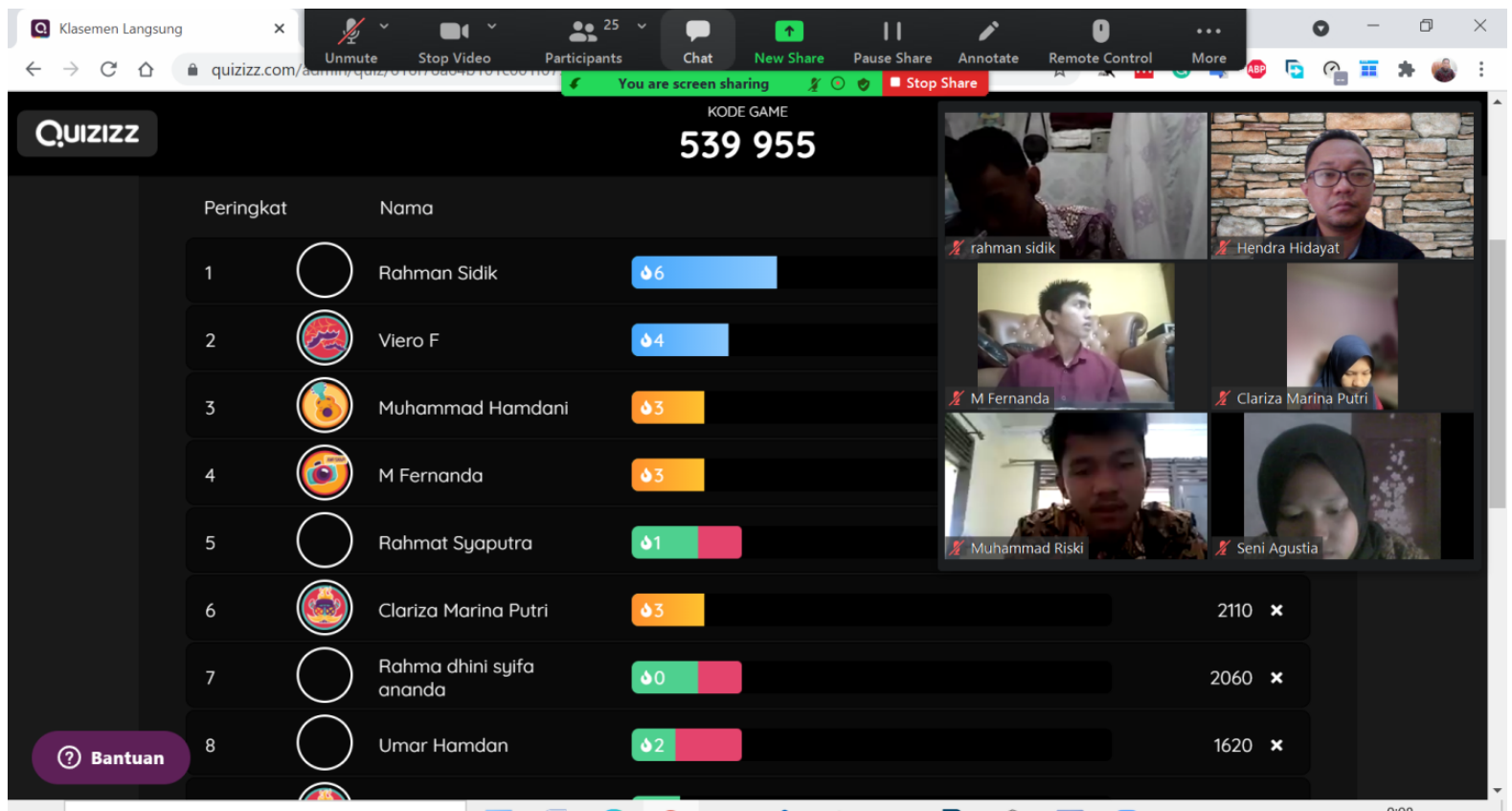

Figure 4. Accuracy of right and wrong answers from students 


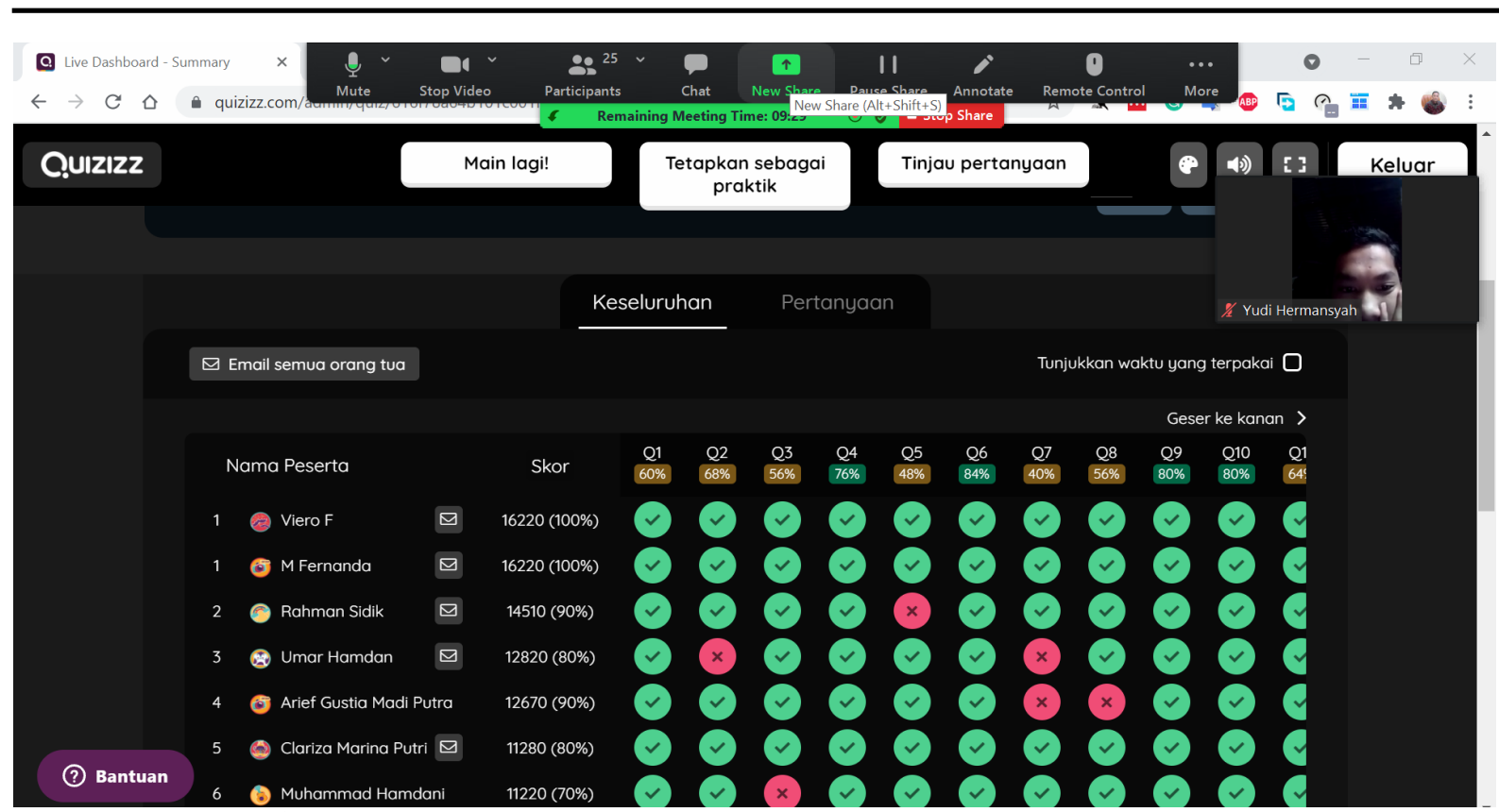

Figure 5. The final results of quizzz directly from all evaluation participants

\section{Quiz Result Assessment}

(1) Click Reports/Results to view student work results; (2) Choose a quiz that will see the results; (3) Lecturers can rearrange the names of quizzes that have been done by students to distinguish quiz results from other classes; (4) Lecturers can see the accuracy of student answers as a whole; (5) On the Participants tab, lecturers can see a list of names, correct answers, and grades of students who have taken the quiz. The accuracy of the answers is the percentage of correct answers from all questions that are done by students, so that the accuracy of the answers can also be used as the final score for the quiz. While what is meant by the value on Quizizz is the point that students get when doing quizzes, These points can come from the accuracy of the answers and the speed with which students answer questions so that the number of these scores reaches the thousands and is more difficult to use as a rating scale in general. Therefore, accuracy/accuracy should be the benchmark for the final score of the quiz; (6) Click a student's name on the Participants tab. Furthermore, the details of the quiz work from the student will appear, namely the correct and incorrect answers, and there are also details of the time needed for the student to answer each question; (7) Click the Participant tab if the lecturer wants to see a detailed analysis of each question on the quiz done by students; (8) Click on a question, then a list of student answers will appear and the time it takes for students to answer the question; (9) Click the Overall tab if the lecturer wants to see the results of the recap of the scores of all participants in terms of each question on the quiz; (10) If the lecturer needs the results of a quiz or test in the form of a softfile, the lecturer can click the download icon. The downloaded file is of type excel; (11) Click the print icon if the lecturer requires quiz or test results in hardfile form.

Quiz implementation in the form of a final assessment or several meetings can be done with Live Quiz on Quizizz. By using Live Quiz, exams are conducted simultaneously so as to minimize cheating in exams and increase student discipline. Students are required to be on time and not delay taking the exam in order to access the Live Quiz. For this reason, before the examination, the lecturer should emphasize that the final assessment in the form of a quiz is carried out through Live Quiz simultaneously and all students are required to take it. However, before administering the exam, the lecturer must also ensure that students understand the technicalities of taking the exam on Quizizz. From the description above, it can be seen that the evaluation of learning in the form of an exam can be done through sites or online applications such as Quizizz with a relatively easy process. Quizizz is easy to use because it offers a variety of features to facilitate and manage the creation of questions in an educational context. So that no special skills are needed for students or lecturers to access quizzes or exams through Quizizz.

Assessment is one of the important things in the exam because the score can represent the student's ability to master the subject matter. The automatic and detailed assessment system on Quizizz is very helpful for lecturers in analyzing student abilities as well as analyzing the validity of the question, very helpful in processing the assessment results (Priyanti, Santosa, \& Dewi, 2019). The results of this study state that the features on Quizizz can make it easier for lecturers to give assignments and assessments that can be downloaded and shared with students. The Quizizz application can be used as a means of storing questions and 
then analyzing the questions so that they become valid, reliable and have different strengths and a good level of difficulty (Zainuddin et al., 2020).

Evaluation of learning in the form of exams or relative daily assessments is seen as a scary and stressful thing for students. However, by evaluating learning through Quizizz students consider the quiz to be fun and can increase motivation to learn, because Quizizz also helps students concentrate on studying and relieves boredom (Zhao, 2019). The use of quiz applications can be used as a medium for giving quizzes to students whose results have a very significant effect on student learning motivation (Dhamayanti, 2021). Quizizz has various advantages so it is worthy of being used as an online learning evaluation medium. However, there are several disadvantages when using Quizizz, one of which is Quizizz relies heavily on a good internet network. This is a major problem when online learning is carried out, because there are several areas that have unstable internet networks (Hamid, Sentryo, \& Hasan, 2020).

Based on the results of interviews with lecturers of electronic components in the electronics engineering study program, one of Quizizz's weaknesses is that each question on the quiz has its own time duration so that sometimes students panic and rush when working. Time allocation is Quizizz's weakness because each question has its own time duration so students who are not good at time management feel uncomfortable (Göksün, \& Gürsoy, 2019). However, this problem can be solved by changing the settings so that students cannot see the countdown time when doing tests on the activity setting.

The demand to produce quality and competitive higher education graduates is currently very necessary (Hidayat et al., 2019c; Hidayat et al., 2021), so it is necessary to consider and think about information technology-based learning activities (Tasrif et al., 2021). ), and online learning evaluation is no exception (Mulya, Ambiyar, \& Wakhinuddin, 2020). Furthermore, the evaluation of learning in the current pandemic era and digital challenges is a new thought by making a breakthrough from manual to online evaluation, one of which is the implementation of Quizizz in learning in higher education.

\section{Conclusion}

The conditions of the pandemic and post-Covid-19 pandemic require the implementation of online and mixed learning, between face-to-face and online. Distance learning really needs to consider effective and efficient evaluation. Evaluation of learning types of tests or final assessments can be done through Quizizz by maximizing the use of the quiz feature on Quizizz supported by guidance from the lecturer. Quizizz is not only used as a learning tool, besides that, Quizizz also has many features that make it easier for lecturers to make assessments that are carried out automatically by the application system directly.

\section{References}

Abidah, A., Hidaayatullaah, HN, Simamora, RM, Fehabutar, D., \& Mutakinati, L. (2020). The impact of covid-19 to Indonesian education and its relation to the philosophy of "free learning". Studies in Philosophy of Science and Education, 1(1), 38-49.https://doi.org/10.46627/sipose.v1i1.9

Amalia, DF (2020). Quizizz Website as an Online Assessment for English Teaching and Learning: Students' Perspectives. Jo-ELT (Journal of English Language Teaching) Faculty of Language \& Arts Education English Language Education Study Program IKIP, 7(1), 1-8.https://doi.org/10.33394/jo-elt.v7i1.2638

Anwar, M., Triyono, M., Ta'ali, T., Hidayat, H., \& Syahputeri, V. (2021). Design of trainer kit as a fault-finding based on electricity and electronics learning media. Journal of Vocational Education, 11(2), 191202.https://doi.org/10.21831/jpv.v11i2.43742

Ardi, Z., Hidayat, H., Ifdil, I., Guspriadi, Y., \& Fauziyyah, SA (2021). The Development of POTENTIA; The AndroidBased Psychological Application for Mapping and Assessments of Student Mental Health During the COVID-19 Pandemic. International Journal of Interactive Mobile Technologies, 15(16).https://doi.org/10.3991/ijim.v15i16.25147

Asria, L., \& Putrie, DR (2021). Students' Perception of Mathematics Education on the Use of the Quizizz Platform as an Online-Based Learning Outcome Evaluation Media. MATH LOCUS: Journal of Mathematics Education Research and Innovation, 2(1), 34-43. https://doi.org/10.31002/mathlocus.v2i1.1466

Baartman, LK, Bastiaens, TJ, Kirschner, PA, \& Van der Vleuten, CP (2007). Evaluating assessment quality in competence-based education: A qualitative comparison of two frameworks. Educational research review, 2(2), 114-129. https://doi.org/10.1016/j.edurev.2007.06.001

Bovill, C. (2020). Co-creation in learning and teaching: the case for a whole-class approach in higher education. Higher Education, 79(6), 1023-1037. https://doi.org/10.1007/s10734-019-00453-w 
Brassler, M., \& Dettmers, J. (2017). How to enhance interdisciplinary competence-interdisciplinary problembased learning versus interdisciplinary project-based learning. Interdisciplinary Journal of ProblemBased Learning, 11(2), 12. https://doi.org/10.7771/1541-5015.1686

Darmawan, MS, Daeni, F., \& Listiaji, P. (2020). The Use of Quizizz As An Online Assessment Application for Science Learning in The Pandemic Era. Unnes Science Education Journal, 9(3), 144150.https://doi.org/10.15294/usej.v9i3.41541

Dhamayanti, FI (2021). EFL Students' Perception and Motivation Toward Quizizz as E-Learning Media in English E-Classroom. EDUCAFL: Journal of Education of English as a Foreign Language, 4(2), 7178.https://doi.org/10.21776/ub.educafl.2021.004.02.03

Ganefri., Hidayat, H., Kusumaningrum, I., \& Mardin, A. (2017). Needs Analysis of Entrepreneurships Pedagogy of Technology and Vocational Education with Production Base Learning Approach in Higher Education. International Journal on Advanced Science, Engineering and Information Technology, 7(5), 17011707.http://dx.doi.org/10.18517/ijaseit.7.5.1510

Ganefri, G., Hidayat, H., Yulastri, A., \& Ifdil, I. (2020). Need analysis of the production based entrepreneurship training model: learning entrepreneurship in higher education. COUNS-EDU: The International Journal of Counseling and Education, 5(2), 58-63.http://dx.doi.org/10.23916/0020200528530

Ganefri, G., Hidayat, H., Yulastri, A., \& Yondri, S. (2021). The empirical analysis of production-based entrepreneurship training model, readiness and locus of control towards students entrepreneurship selfefficacy. International Journal of Research in Counseling and Education, 5(1), 5661.https://doi.org/10.24036/00434za0002

Göksün, DO, \& Gürsoy, G. (2019). Comparing success and engagement in gamified learning experiences via Kahoot and Quizizz. Computers \& Education, 135, 15-29.https://doi.org/10.1016/j.compedu.2019.02.015

Hamid, R., Sentryo, I., \& Hasan, S. (2020). Online learning and its problems in the Covid-19 emergency period. Prima Edukasia Journal, 8(1), 86-95.http://dx.doi.org/10.21831/jpe.v8i1.32165

Hidayat, H. (2017). How is the Application and Design of a Product-Based Entrepreneurship Learning Tools in Vocational Higher Education?. Advances in Social Science, Education and Humanities Research, volumes 102, 223-228.http://dx.doi.org/10.2991/ictvt-17.2017.38.

Hidayat, H., Herawati, S., Syahmaidi, E., Hidayati, A., \& Ardi, Z. (2018). Designing of technopreneurship scientific learning framework in vocational-based higher education in Indonesia. International Journal of Engineering and Technology(UAE), 7(4), 123-127.https://doi.org/10.14419/ijet.v7i4.9.20632

Hidayat, H., Tamin, BY, Herawati, S., Khairul, K., \& Syahmaidi, E. (2019a). The contribution of technopreneurship scientific learning and learning readiness towards the entrepreneurship learning outcomes in higher vocational education. Journal of Vocational Education, 9(1), 2132.http://dx.doi.org/10.21831/jpv.v9i1.20466

Hidayat, H., Tamin, BY, Herawati, S., Hidayati, A., Muji, AP (2019b). Implementation of technopreneurship scientific learning to produce electronic product prototypes in engineering education. International Journal of Innovative Technology and Exploring Engineering, 8(11), 28422846.http://dx.doi.org/10.35940/ijitee.K2406.0981119

Hidayat, H., Ardi, Z., Yuliana, \& Herawati, S. (2019c). Exploration of the need analysis for technopreneurship scientific learning models in higher vocational education. International Journal of Economics and Business Research, 18(3), 356-368.http://dx.doi.org/10.1504/IJEBR.2019.102733

Hidayat, H., Tasrif, E., Jaya, P., Anwar, M., Hadi, A., Cultural, K., ... \& Asmara, D. (2021). The Empirical Analysis of Industrial Work Challenges in the Industrial Revolution 5.0 Towards a Grade Point Average (GPA) for Electronic Engineering Education Students. International Journal of Online \& Biomedical Engineering, 17(9).https://doi.org/10.3991/ijoe.v17i09.25679

McGrew, S., Breakstone, J., Ortega, T., Smith, M., \& Wineburg, S. (2018). Can students evaluate online sources? Learning from assessments of civic online reasoning. Theory \& Research in Social Education, 46(2), 165193.https://doi.org/10.1080/00933104.2017.1416320

Mohajan, HK (2018). Qualitative research methodology in social sciences and related subjects. Journal of Economic Development, Environment and People, 7(1), 23-48.https://doi.org/10.26458/jedep.v7i1.571

Mulya, R., Ambiyar, A., \& Wakhinuddin, W. (2020). Evaluation of Moodle-Based Online Learning in the Operating System Course. Education: Journal of Education, 18(1), 3949.http://dx.doi.org/10.31571/edukasi.v18i1.1653 
Nilsson, P. (2008). Teaching for understanding: The complex nature of pedagogical content knowledge in preservice education. International Journal of Science Education, 30(10), 12811299.https://doi.org/10.1080/09500690802186993

Okay, A., \& Fernandes, FAP (2020). Innovations in teaching and learning: Exploring the perceptions of the education sector on the 4th industrial revolution (4IR). Journal of Open Innovation: Technology, Market, and Complexity, 6(2), 31.https://doi.org/10.3390/joitmc6020031

Priyanti, NWI, Santosa, MH, \& Dewi, KS (2019). Effect Of Quizizz Towards The Eleventh-Grade English Students'reading Comprehension In Mobile Learning Context. Language and Education Journal Undiksha, 2(2), 71-80.http://dx.doi.org/10.23887/leju.v2i2.20323

Purba, L. S. L. (2019). Peningkatan konsentrasi belajar mahasiswa melalui pemanfaatan evaluasi pembelajaran quizizz pada mata kuliah kimia fisika I. Jurnal Dinamika Pendidikan, 12(1), 29-39. https://doi.org/10.51212/jdp.v12i1.1028

Sadler, DR (2010). Beyond feedback: Developing student capability in complex appraisal. Assessment \& evaluation in higher education, 35(5), 535-550.https://doi.org/10.1080/02602930903541015

Suo Yan, Zalika, \& Mei, SY (2018). Implementing Quizizz as Game Based Learning in the Arabic Classroom. European Journal of Social Science Education and Research, 5(1), 194 198.https://doi.org/10.26417/ejser.v12i1.p208-212

Tasrif, E., Saputra, HK, Kurniadi, D., Hidayat, H., \& Mubai, A. (2021). Designing Website-Based Scholarship Management Application for Teaching of Analytical Hierarchy Process (AHP) in Decision Support Systems (DSS) Subjects. International Journal of Interactive Mobile Technologies, 16(9). https://doi.org/ 10.3991/ijim.v15i09.23513

Zhao, F. (2019). Using Quizizz to Integrate Fun Multiplayer Activity in the Accounting Classroom. International Journal of Higher Education, 8(1), 37-43.https://doi.org/10.5430/ijhe.v8n1p37

Zainuddin, Z., Shujahat, M., Haruna, H., \& Chu, SKW (2020). The role of gamified e-quizzes on student learning and engagement: An interactive gamification solution for a formative assessment system. Computers \& Education, 145, 103729.https://doi.org/10.1016/j.compedu.2019.103729

Zuhriyah, S., \& Pratolo, BW (2020). Exploring Students' Views in the Use of Quizizz as an Assessment Tool in English as a Foreign Language (EFL) Class. Universal Journal of Educational Research, 8(11), 53125317.https://doi.org/10.13189/ujer.2020.081132 